点

I N S AN

INSAN

Jurnal Psikologi dan Kesehatan Mental

http://e-journal.unair.ac.id/index.php/JPKM

p-ISSN 2528-0104 | e-ISSN 2528-5181

LAPORAN KASUS

\title{
Metode Positive Behavior Support untuk Mengelola Emosi dan Perilaku pada Anak dengan Oppositional Defiant Disorder
}

ANDI AHMAD RIDHA

Fakultas Psikologi, Universitas Airlangga

\begin{abstract}
ABSTRAK
Penelitian ini bertujuan untuk mengetahui efektivitas intervensi positive behavior support untuk mengelola emosi dan perilaku pada anak dengan oppositional defiant disorder. Partisipan dalam penelitian ini adalah satu orang, yaitu seorang anak laki-laki berusia 11 tahun yang mengalami oppositional defiant disorder. Penelitian ini adalah penelitian single case experimental design. Instrumen penelitian ini berupa lembar observasi dan wawancara berdasarkan DSM V. Analisis terhadap data yang diperoleh menggunakan analisis deskriptif untuk menjelaskan perubahan perilaku yang ditunjukkan partisipan sebelum dan setelah pemberian intervensi. Hasil penelitian ini menunjukkan bahwa terdapat perubahan yang positif pada diri partisipan dalam mengelola emosi dan perilaku setelah diberikan intervensi positive behavior support. Oleh karena itu, dapat disimpulkan bahwa metode positive behavior support efektif untuk mengelola emosi dan perilaku anak dengan oppositional defiant disorder.
\end{abstract}

Kata kunci: emosi dan perilaku, positive behavior support, oppositional defiant disorder

\begin{abstract}
This study aimed to determine the effectiveness of positive behavior support interventions to manage emotions and behavior in children with oppositional defiant disorder. The participant in this study was a 11-year-old boy who was diagnosed with oppositional defiant disorder. This research was single case experimental design. The measurement strategy in this research was employing an observation sheet and interview based on DSM V. Analysis of the data obtained using descriptive analysis to explain the behavioral changes shown by the subjects before and after the intervention. The results of this study indicated that there were positive changes in the subject in managing emotions and behavior after being given a positive behavior support intervention. Therefore, it can be concluded that the positive behavior supports is effective for managing children's emotions and behavior with oppositional defiant disorder.
\end{abstract}

Keywords: emotion and behavior, positive behavior support, oppositional defiant disorder 
INSAN Jurnal Psikologi dan Kesehatan Mental, 2020, Vol. 5(2), 150-161, doi: 10.20473/jpkm.v5i22020.150-161 Dikirimkan: 2 April 2018 Diterima: 29 Oktober 2020 Diterbitkan: 2 November 2020

Editor: Rizqy Amelia Zein

*Alamat korespondensi: Fakultas Psikologi Universitas Airlangga, Kampus B Universitas Airlangga Jalan Airlangga 4-6 Surabaya 60286. Pos-el: ridho.abdillah92@gmail.com

Naskah ini merupakan naskah dengan akses terbuka dibawah ketentuan the Creative Common Attribution License (http://creativecommons.org/licenses/by-sa/4.0), sehingga penggunaan, distribusi, reproduksi dalam media apapun atas artikel ini tidak dibatasi, selama sumber aslinya disitir dengan baik.

\section{P E N D A H U L UA N}

Oppositional defiant disorder (ODD) merupakan sebuah gangguan pada masa kanak-kanak yang ditandai dengan ketidakmampuan dalam mengontrol diri, tidak patuh, menantang, dan menunjukkan perilaku mengganggu dalam lingkungan sosial. Diagnosis ODD hanya diberikan jika perilaku menentang dan menantang secara signifikan mengganggu proses akademik, sosial, dan kemampuan adaptasi individu (Stamp, 2005). Menurut AACP (2009) bahwa ODD merupakan salah satu dari kelompok disruptive behavior disorder karena anak-anak yang memiliki gangguan ini cenderung mengganggu orang di sekitar mereka. ODD adalah salah satu gangguan yang lebih umum ditemukan pada anak-anak dan remaja. ODD didiagnosa sebagai pola perilaku yang tidak taat, bermusuhan, dan menantang orang dewasa. Anak-anak dan remaja yang mengalami ODD, sering memberontak, keras kepala, berdebat dengan orang dewasa, dan menolak untuk mematuhi aturan. Mereka memiliki ledakan amarah dan kesulitan dalam mengendalikan emosi. Individu dengan ODD menunjukkan pola marah dan perilaku verbal agresif yang konstan, biasanya ditujukan untuk orang dewasa dan otoritas lainnya.

Berdasarkan temuan kasus, penulis telah melakukan pendampingan psikologis selama kurang lebih dua bulan (dari bulan Maret-Juni 2017) dengan seorang partisipan berinisial RG. Dari hasil pendampingan, observasi dan wawancara secara berkala dengan menggunakan DSM V, peneliti menemukan bahwa partisipan mengalami gejala ODD dengan level sedang yang ditandai dengan sebuah pola perilaku yang secara terus-menerus menunjukkan suasana hati yang mudah tersinggung, sensitif, mudah marah, argumentatif, menolak aturan, dan sering iri atau dendam.

Berdasarkan hasil asesmen, diketahui bahwa partisipan cenderung memiliki masalah dalam mengelola emosi dan perilakunya seperti mudah marah, sensitif, mengucapkan kata-kata kasar, dan membantah orang dewasa. Hal ini didukung oleh tes CBCL bahwa partisipan memiliki masalah dalam aspek externalizing dengan kategori clinical. Hal ini menunjukkan bahwa partisipan membutuhkan penanganan segera dalam mengatasi permasalahannya. Partisipan menunjukkan permasalahan delinquent behavior, seperti suka berkata kasar dan melempar barang ketika marah, partisipan juga berteman dengan orang-orang yang lebih tua. Selain itu, partisipan memiliki permasalahan aggressive behavior, ia sering menunjukkan perilaku agresif seperti sering bertengkar, terlibat perkelahian, melawan orang dewasa, sering marah-marah, dan sangat sensitif.

Perilaku partisipan yang bermasalah bermula dari hubungan kedua orang tua yang kurang harmonis. Perilaku partisipan yang bermasalah mulai tampak pada saat partisipan berusia 3 tahun namun orang tua kurang memperhatikan perilaku partisipan. Orang tua justru membiarkan partisipan berada di lingkungan kerja orang tua yang mayoritas pekerjanya sering mengeluarkan kata-kata kasar. Partisipan bergaul dengan pekerja yang ada di toko, partisipan berada di toko sejak pulang sekolah hingga toko 
ibunya tutup. Partisipan sudah berada di lingkungan kerja orang tua sejak usia 7 tahun sehingga partisipan memiliki teman bergaul yang cenderung lebih tua dari usianya.

Partisipan ingin diperhatikan sehingga mendominasi orang-orang di sekitarnya. Partisipan yang cukup impulsif dan agresif dalam bergaul menyebabkan ia kurang diterima di lingkungan sosial sehingga menjadikan partisipan mudah frustrasi dalam menghadapi setiap masalah yang ditemuinya. Partisipan memiliki sifat egosentris yang cukup kuat sehingga ia kurang begitu baik dalam membina hubungan sosialnya. Partisipan yang kurang mampu mengontrol emosinya, menyebabkan partisipan kurang mampu membina pertemanan yang akrab. Pada dasarnya, partisipan memiliki kecerdasan yang cukup baik, partisipan senang berkompetisi namun kurang mampu menghormati orang lain, partisipan sering membantah, menentang, dan menantang guru, sensitif, mudah tersinggung, sering mengganggu temantemannya, dan tidak ingin disalahkan. Di sekolah, partisipan merasa bahwa dirinya selalu disalahkan oleh guru meskipun pada dasarnya partisipan yang selalu memulai mencari masalah dengan orang lain. Ketidakmampuan partisipan dalam mengelola emosi berdampak pada perilakunya yang mudah marah dan argumentatif.

Dadds dan Fraser (2003) mengemukakan bahwa faktor penyebab dari ODD dipandang sebagai seperangkat sistem, subsistem, dan komponen sistem yang berinteraksi dalam aspek biologis, interpersonal, keluarga, dan tingkat sosial. Meskipun masalah masing-masing anak mungkin berhubungan dengan pola yang berbeda dari faktor risiko, ada kemungkinan bahwa ada kriteria umum yang menggambarkan terjadinya masalah perilaku. Burke, Loeber, dan Lahey (2003) mengemukakan bahwa hal yang esensial dari ODD adalah pola berulang dari perilaku menantang, perilaku tidak taat, dan menampilkan sikap bermusuhan terhadap figur otoritas, sedangkan hal yang esensial dari CD adalah pola perilaku yang berulang-ulang dan gigih untuk melanggar norma-norma sosial.

Positive behavior support (PBS) adalah suatu pendekatan yang digunakan untuk meningkatkan fungsi akademik dan sosial yang positif dalam lingkungan sekolah. Penggunaan intervensi ini terbukti efektif dapat mengurangi perilaku menantang pada anak dan mengurangi timbulnya masalah perilaku di sekolah (Matthys \& Lochman, 2010). PBS adalah pendekatan pemecahan masalah untuk memahami alasan perilaku bermasalah dan merancang intervensi yang komprehensif. Sebuah tujuan penting dari PBS, tidak hanya untuk mengurangi masalah perilaku dalam jangka pendek, tetapi juga untuk menciptakan perubahan jangka panjang yang akan berdampak pada individu kualitas hidup secara keseluruhan (Bambara \& Kern, 2005).

PBS ditandai dengan intervensi yang edukatif, proaktif, dan hormat yang melibatkan pengajaran keterampilan alternatif untuk siswa yang berperilaku bermasalah dan perubahan lingkungan yang berkontribusi terhadap masalah perilaku. PBS memadukan praktik terbaik dalam teknologi perilaku, pendidikan, metode, dan sistem ekologi berubah dengan nilai-nilai person-centered, untuk mencapai hasil yang bermakna dan relevan dengan siswa, keluarganya, dan lain-lain yang terlibat dalam pendidikan siswa (Bambara \& Kern, 2005).

Berdasarkan latar belakang tersebut, diketahui bahwa PBS merupakan salah satu alternatif intervensi yang telah terbukti efektif dapat digunakan dalam menangani anak yang mengalami gangguan emosi dan perilaku. Oleh karena itu, peneliti tertarik untuk melihat dampak dari pemberian intervensi PBS sebagai upaya dalam mengelola emosi dan perilaku anak dengan ODD. Adapun tujuan dari penelitian ini yaitu untuk mengetahui efektivitas intervensi PBS dalam mengurangi permasalahan emosi dan perilaku anak dengan ODD. 


\section{ME T O D E}

\section{Partisipan Penelitian}

Partisipan dalam penelitian ini adalah seorang siswa kelas V SD wilayah Semampir, Surabaya. Partisipan penelitian berusia 11 tahun yang telah didiagnosa mengalami ODD level sedang. Desain yang digunakan dalam eksperimen ini adalah single case experiment design. Penelitian ini merupakan suatu penelitian eksperimen dengan studi kasus yaitu dengan cara memahami lebih dalam terhadap suatu kasus yang akan diteliti. Dalam hal ini yaitu meneliti pengaruh intervensi PBS dalam mengelola emosi dan perilaku anak dengan ODD.

\section{Instrumen Penelitian}

Instrumen yang digunakan dalam penelitian ini berupa lembar observasi dan wawancara yang mengacu pada gejala-gejala ODD berdasarkan DSM V. Penilaian dilakukan dalam dua tahap yaitu 1) sebelum diberikan intervensi, pada saat proses asesmen, dan 2) setelah diberikan intervensi PBS, untuk mengevaluasi perubahan-perubahan partisipan dalam mengelola emosi. Selain itu, dalam penelitian ini juga menggunakan alat eksperimen berupa panduan program intervensi PBS yang telah disusun peneliti berdasarkan karakteristik ODD yang dimiliki partisipan.

\section{Intervensi}

Intervensi yang diberikan yaitu positive behavior support (PBS). PBS yang disusun peneliti telah disesuaikan dengan hasil asesmen yang telah dilakukan sebelumnya. Bambara dan Kern (2005) mengemukakan bahwa terdapat lima langkah dalam melakukan PBS. Proses PBS tersebut dapat diterapkan secara efektif pada siswa dengan berbagai diagnosa (misalnya, cacat, gangguan emosional dan perilaku dalam belajar, keterbelakangan mental, autisme), masalah perilaku (misalnya, agresi, disruptif, menyakiti diri sendiri, withdrawal), dan dari berbagai situasi (misalnya, rumah, sekolah, masyarakat). Adapun langkah-langkahnya, yaitu, 1) menentukan prioritas dan mendefinisikan perilaku yang dianggap bermasalah; 2) melakukan analisis fungsional; 3) merumuskan hipotesis; 4) mengembangkan rencana PBS; dan 5) mengimplementasikan, mengevaluasi, dan memodifikasi PBS. Penulis bekerjasama dengan wali kelas dan orang tua dalam menerapkan intervensi PBS kepada partisipan. Pelaksanaan intervensi dimulai sejak bulan Maret-September 2017.

\section{Teknik Analisis Data}

Teknik analisis data yang digunakan yaitu metode analisis deskriptif. Dalam penelitian ini yaitu membandingkan perilaku partisipan sebelum dan setelah diberikan intervensi PBS.

\section{HAS IL PE NELITIAN}

Intervensi yang diberikan kepada partisipan adalah metode positive behavior support untuk membantu partisipan mengelola emosi dan perilakunya. Adapun yang menjadi target dalam intervensi ini yaitu untuk mengurangi timbulnya masalah emosi dan perilaku partisipan di sekolah maupun di rumah. Penulis bekerjasama dengan wali kelas dan orang tua dalam melaksanakan PBS sambil memberikan psikoedukasi kepada wali kelas dan orang tua. Selama menerapkan PBS, penulis meminta kepada wali kelas dan orang tua untuk memantau perubahan atau kemajuan yang dialami partisipan. Adapun INSAN Jurnal Psikologi dan Kesehatan Mental 2020, Vol. 5(2), 150-161 
perilaku partisipan sebelum diberikan intervensi dapat terlihat dari hasil observasi perilaku. Berdasarkan observasi dapat disimpulkan bahwa perilaku negatif yang ditampakkan partisipan terjadi pada dua setting yaitu di sekolah dan di lokasi kerja orang tua. Partisipan secara konsisten menunjukkan perilaku negatif pada mata pelajaran matematika, agama, IPA, saat jam istirahat, dan pelajaran BTQ. Adapun frekuensi terjadinya perilaku yang ditampilkan oleh partisipan dapat dilihat pada Tabel 1.

Tabel 1. Hasil Observasi Perilaku Partisipan Sebelum Intervensi

\begin{tabular}{|c|c|c|c|c|c|c|c|}
\hline \multirow{2}{*}{ Perilaku } & \multicolumn{7}{|c|}{ Total Frekuensi } \\
\hline & $\mathbf{H}_{1}$ & $\mathbf{H}_{2}$ & $\mathbf{H}_{3}$ & $\mathbf{H}_{4}$ & $\mathbf{H}_{5}$ & $\mathbf{H}_{6}$ & $\mathbf{H}_{7}$ \\
\hline \multicolumn{8}{|l|}{ Marah } \\
\hline Menyerang orang lain secara fisik & & & 2 & 4 & 6 & & 6 \\
\hline Sensitif terhadap penilaian orang lain & 2 & & 3 & 3 & 4 & & 2 \\
\hline Membentak orang lain & & & 2 & 8 & 14 & & 10 \\
\hline Memukul meja & & & 5 & & & & 14 \\
\hline \multicolumn{8}{|l|}{ Argumentatif/ Memberontak } \\
\hline $\begin{array}{l}\text { Bercerita dengan teman saat guru sedang } \\
\text { mengajar }\end{array}$ & & 12 & 5 & & 5 & & \\
\hline Menolak mematuhi perintah orang lain & 5 & 2 & 2 & & 9 & & 9 \\
\hline Memaki orang lain & & 6 & 3 & 4 & 35 & & 15 \\
\hline Menentang orang lain & & & 3 & 5 & 12 & 8 & 13 \\
\hline Menyalahkan orang lain & & & 5 & 3 & 22 & & 13 \\
\hline Sengaja mengganggu orang lain & & & & 8 & 23 & 5 & 23 \\
\hline \multicolumn{8}{|l|}{ Dendam } \\
\hline Mengajak berkelahi & & & 3 & 2 & 5 & & 7 \\
\hline
\end{tabular}

Adapun penjelasan proses intervensi akan dijabarkan sebagai berikut:

\section{Sesi 1: Menentukan Prioritas}

Pada sesi ini, wali kelas dan orang tua diberikan psikoedukasi mengenai kondisi partisipan yang mengalami ODD. Berdasarkan hasil diskusi, diketahui bahwa terdapat dua prioritas dalam rencana PBS, yaitu 1) perilaku partisipan yang memiliki frekuensi cukup tinggi dalam melakukan agresi verbal seperti membentak, memaki dan menyalahkan orang lain; dan 2) perilaku partisipan yang cukup konfrontatif seperti menentang dan menolak mematuhi perintah orang lain.

\section{Sesi 2: Analisis Fungsional}

Selanjutnya, orang tua dan wali kelas diminta untuk melakukan analisis fungsional berdasarkan konsep $\mathrm{ABC}$, antecedents (peristiwa pendahulu yang berupa fakta, kejadian, perilaku atau sikap orang lain), behavior (perilaku yang ditunjukkan), dan consequences (kejadian-kejadian yang mengikuti perilaku). Adapun hasil analisis fungsional dapat dilihat pada Tabel 2. 
Tabel 2. Hasil Analisis Fungsional terhadap Perilaku Partisipan

\begin{tabular}{|c|c|c|}
\hline Antecedents & Behavior & Consequences \\
\hline $\begin{array}{l}\text { Guru menjelaskan pelajaran } \\
\text { agama Islam }\end{array}$ & $\begin{array}{l}\text { Partisipan memukul-mukul } \\
\text { meja }\end{array}$ & $\begin{array}{l}\text { Guru menegur partisipan } \\
\text { berulang kali }\end{array}$ \\
\hline $\begin{array}{l}\text { Guru agama meminta } \\
\text { partisipan keluar kelas } \\
\text { karena memukul-mukul meja }\end{array}$ & $\begin{array}{l}\text { Partisipan menentang dan } \\
\text { menantang guru "kenapa aku } \\
\text { harus keluar, aku disini } \\
\text { membayar kok" }\end{array}$ & Guru memarahi partisipan \\
\hline $\begin{array}{l}\text { Pelajaran BTQ sedang } \\
\text { berlangsung }\end{array}$ & $\begin{array}{l}\text { Partisipan menolak bergabung } \\
\text { dengan kelompok belajar, } \\
\text { berkata kasar dan berteriak } \\
\text { pada guru BTQ }\end{array}$ & Guru menegur partisipan \\
\hline $\begin{array}{l}\text { Partisipan disenggol oleh } \\
\text { pekerja JMP }\end{array}$ & $\begin{array}{l}\text { Partisipan marah dan memaki } \\
\text { pekerja, menggerutu dan } \\
\text { memukul kaki pekerja yang } \\
\text { lewat }\end{array}$ & $\begin{array}{l}\text { Pekerja mengabaikan } \\
\text { Partisipan }\end{array}$ \\
\hline $\begin{array}{l}\text { RG sedang bermain game lalu } \\
\text { terdengar adzan shalat ashar } \\
\text { dan ibu meminta partisipan } \\
\text { untuk shalat }\end{array}$ & Partisipan menentang ibunya & Ibu menasehati partisipan \\
\hline $\begin{array}{l}\text { Siswa autis menyenggol kaki } \\
\text { partisipan }\end{array}$ & $\begin{array}{l}\text { Partisipan marah, berkata kasar } \\
\text { pada temannya, menarik dasi } \\
\text { temannya lalu } \\
\text { menyembunyikannya }\end{array}$ & $\begin{array}{l}\text { Wali kelas memarahi } \\
\text { partisipan dan meminta } \\
\text { siswa autis untuk minta } \\
\text { maaf pada partisipan }\end{array}$ \\
\hline $\begin{array}{l}\text { Ayah partisipan meminta } \\
\text { tolong }\end{array}$ & $\begin{array}{l}\text { Partisipan menolak perintah } \\
\text { ayahnya }\end{array}$ & $\begin{array}{l}\text { Ayah memukul dan } \\
\text { memarahi partisipan }\end{array}$ \\
\hline $\begin{array}{l}\text { Guru menjadikan partisipan } \\
\text { sebagai contoh bahwa jika } \\
\text { ada pelajaran yang tidak } \\
\text { dipahami maka segeralah } \\
\text { bertanya seperti yang } \\
\text { dilakukan partisipan }\end{array}$ & $\begin{array}{l}\text { Partisipan marah dan } \\
\text { menghentak-hentakkan kakinya } \\
\text { dan mengatakan bahwa ia bisa } \\
\text { mengerjakan tugas }\end{array}$ & $\begin{array}{l}\text { Menjelaskan bahwa } \\
\text { partisipan adalah teladan } \\
\text { bagi temannya dan tidak } \\
\text { bermaksud untuk } \\
\text { meremehkan partisipan }\end{array}$ \\
\hline
\end{tabular}

\section{Sesi 3: Merumuskan Hipotesis}

Orang tua dan wali kelas dapat merumuskan lima hipotesis yaitu: 1) Ketika ditegur di depan teman kelasnya/diremehkan, partisipan akan berteriak, menghina, dan marah untuk menghindari teguran lebih lanjut dan rasa malu dihadapan teman-temannya; 2) Ketika partisipan sedang tidak melakukan aktivitas apapun atau saat jam istirahat, ia akan mengganggu temannya untuk mendapatkan perhatian; 3) Ketika diberi tugas yang sulit/mengikuti pelajaran yang tidak disukainya, Partisipan menunjukkan perilaku mengganggu, untuk menghindari tugas/aktivitas/pelajaran; 4) Ketika diminta untuk beralih dari kegiatan yang disukai untuk kegiatan belajar, partisipan menolak dan menentang untuk menjaga aktivitasnya dan menghindari kegiatan yang tidak disukainya; dan 5) Ketika ayah partisipan berada di rumah, partisipan menunjukkan perilaku mengganggu untuk menarik perhatian.

\section{Sesi 4: Mengembangkan Rencana PBS}

Adapun bentuk dari PBS yang berhasil dikembangkan oleh orang tua dan wali kelas dapat dilihat pada Tabel 3.

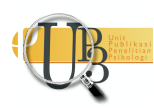


Tabel 3. Pengembangan Rencana PBS untuk Partisipan di Rumah dan di Sekolah

\begin{tabular}{|c|c|}
\hline Komponen PBS & Langkah-langkah Penerapan PBS \\
\hline \multirow{7}{*}{$\begin{array}{l}\text { Antecedent/ } \\
\text { setting event } \\
\text { intervention }\end{array}$} & $\begin{array}{l}\text { a) Memberi porsi yang lebih banyak bagi partisipan untuk berpartisipasi } \\
\text { aktif dalam kegiatan kelas. }\end{array}$ \\
\hline & $\begin{array}{l}\text { b) Minimalkan kegiatan ceramah untuk pelajaran yang tidak disukai, } \\
\text { memberi porsi yang lebih banyak dengan kegiatan praktik. }\end{array}$ \\
\hline & $\begin{array}{l}\text { c) Dalam pelajaran BTQ, meminta partisipan belajar dengan mendengarkan } \\
\text { bacaan al-quran dari mp3/tape recorder/film, lalu mempraktikkannya } \\
\text { sendiri. }\end{array}$ \\
\hline & $\begin{array}{l}\text { d) Jauhkan partisipan dari siswa yang dapat memberi pengaruh buruk dan } \\
\text { perkenalkan teman yang dapat menjadi model yang baik. }\end{array}$ \\
\hline & $\begin{array}{l}\text { e) Di setiap transisi pembelajaran, guru memberikan ekspektasi dari } \\
\text { perilaku siswa secara keseluruhan dan beri apresiasi di akhir } \\
\text { pembelajaran terhadap siswa yang menunjukkan perilaku positif. }\end{array}$ \\
\hline & $\begin{array}{l}\text { f) Mengapresiasi perilaku positif yang ditampakkan partisipan, hindari } \\
\text { memberi perhatian atas perilaku negatif yang ditampakkan partisipan. }\end{array}$ \\
\hline & $\begin{array}{l}\text { g) Di rumah, berikan ekspektasi orang tua dari perilaku partisipan yang } \\
\text { diharapkan. Berikan pujian atas perilaku positif yang dilakukan } \\
\text { partisipan dan hindari memberi perhatian atas perilaku negatif yang } \\
\text { dilakukan partisipan. }\end{array}$ \\
\hline
\end{tabular}

Alternative skill instruction a) Sebelum pelajaran dimulai, secara personal ingatkan partisipan bahwa ia dapat meminta izin kepada guru untuk mengambil air wudhu dan beristirahat sejenak untuk menenangkan amarah dan mendinginkan perasaannya.

b) Ajarkan partisipan agar dapat memonitor dirinya, Partisipan dapat meminta izin tanpa harus berteriak/berkata kasar/marah.

c) Beri pujian pada partisipan dalam membuat pilihan yang baik yaitu meminta izin mengambil air wudhu daripada marah-marah. Laporkan perkembangan kepada orang tua.

d) Di rumah, ajarkan kepada partisipan bahwa ketika partisipan merasa dirinya akan marah, Partisipan dapat berpindah lokasi dan mengambil air wudhu untuk menenangkan dirinya.

Coping and tolerance skills:

a) Secara personal, gunakan role play untuk mengajar partisipan mengidentifikasi pemicu kemarahan lalu bersantai dengan menghitung sampai 10. Ingatkan partisipan bahwa jika dia tidak bisa tetap tenang di tempat yang biasa di dalam kelas, dia selalu memiliki pilihan untuk meminta izin mengambil air wudhu.

b) Minta partisipan memonitor dirinya, tinggal di tempat duduknya dan tetap tenang.

c) Lakukan evaluasi bersama partisipan setelah jam pulang sekolah. Laporkan perkembangan pada orang tua.

General adaptif skills:

a) Secara personal, dorong partisipan untuk menemukan solusi atas peristiwa yang menyebabkan partisipan ditegur oleh guru.

b) Dorong partisipan untuk menetapkan tujuan spesifik dan memantau kinerjanya di dalam kelas dengan menggunakan checklist pemantauan 
diri (misalnya, "Saya berhasil mengerjakan tugas hari ini", "Saya menghormati guru di kelas"). Ajak partisipan meluangkan waktu untuk melakukan pemantauan diri dan tetap tenang.

c) Lakukan evaluasi setelah pulang sekolah. Bantu partisipan menemukan solusi untuk masalah baru yang mungkin dialaminya.

d) Wali kelas bekerjasama dengan orang tua siswa untuk mempersiapkan hadiah jika partisipan dapat menunjukkan perilaku yang positif selama rentang waktu tertentu.

\begin{tabular}{|c|c|}
\hline $\begin{array}{l}\text { Responses to } \\
\text { problem } \\
\text { behavior }\end{array}$ & $\begin{array}{l}\text { a) Ketika partisipan mulai menampakkan gejala akan mengganggu, terapkan } \\
\text { teknik extinction yaitu menahan untuk memberikan perhatian sebelum } \\
\text { partisipan menunjukkan perilaku yang diharapkan. Ketika partisipan } \\
\text { tenang, beri pujian. } \\
\text { b) Jika perilaku berlanjut, lakukan brainstorming untuk menentukan } \\
\text { mengapa ia berperilaku mengganggu, berikan penjelasan yang logis } \\
\text { tentang kesalahannya. Minta partisipan untuk meminta maaf kepada } \\
\text { orang lain untuk kata-kata atau komentar yang tidak pantas. Berikan } \\
\text { umpan balik dengan tetap tenang dan diam. } \\
\text { c) Jika partisipan sudah mulai menunjukkan perilaku agresif seperti } \\
\text { memukul, marah-marah, dan mengeluarkan kata-kata kasar, segera } \\
\text { lakukan crisis management. } \\
\text { Crisis management } \\
\text { a) Singkirkan material berbahaya di dekat partisipan yang dapat digunakan } \\
\text { untuk mencederai orang lain. } \\
\text { b) Minta teman-teman kelas untuk tenang dan tidak memberi perhatian } \\
\text { pada partisipan. } \\
\text { c) Gunakan teknik time out yaitu dengan membawa partisipan keluar kelas } \\
\text { menuju lokasi lain untuk menenangkan diri, jelaskan alasan mengapa ia } \\
\text { dibawa keluar kelas, setelah emosinya mereda, ajak partisipan diskusi } \\
\text { menemukan solusi dalam menyelesaikan masalah. Bawa kembali ke kelas } \\
\text { setelah partisipan tenang dan beri pujian. }\end{array}$ \\
\hline $\begin{array}{l}\text { Long-term } \\
\text { supports }\end{array}$ & $\begin{array}{l}\text { Lifestyle changes } \\
\text { a) Membuat suasana pembelajaran lebih kontekstual dengan kehidupan } \\
\text { sehari-hari siswa. } \\
\text { b) Minimalkan kesempatan partisipan untuk melakukan kegiatan-kegiatan } \\
\text { negatif seperti bermain gadget, bergaul dengan teman-teman yang } \\
\text { bermasalah, dan membiarkan partisipan tidak memiliki aktivitas } \\
\text { bermanfaat sepanjang hari. } \\
\text { c) Beri kesempatan bagi partisipan untuk melaksanakan amanah/memiliki } \\
\text { tanggung jawab di sekolah maupun di rumah. } \\
\text { Strategies to sustain support } \\
\text { a) Memberikan edukasi pada guru-guru tentang kondisi partisipan yang } \\
\text { mengalami ODD. } \\
\text { b) Beri pemahaman kepada seluruh pihak keluarga agar memberikan } \\
\text { teladan yang positif kepada partisipan. } \\
\text { c) Jalin komunikasi yang hangat antara orang tua dan partisipan, orang tua } \\
\text { memberi pemahaman bahwa apapun alasan yang dikemukakan } \\
\text { partisipan, mengganggu orang lain, marah, memukul, berkata kasar } \\
\text { adalah perilaku yang tidak terpuji dan tidak layak untuk dicontoh. }\end{array}$ \\
\hline
\end{tabular}


d) Jalin komunikasi yang hangat antara guru dan partisipan, beri perhatian pada hal-hal positif yang dilakukan partisipan.

\section{Sesi 5: Implementasi dan Evaluasi Strategi}

Pada sesi ini, orang tua dan wali kelas diminta untuk mengimplementasikan rencana PBS yang telah dikembangkan sebelumnya. Orang tua dan wali kelas menyatakan bersedia menerapkan strategi PBS pada partisipan. Proses intervensi PBS berlangsung sejak tanggal 27 Maret 2017 hingga 5 September 2017. Setelah mengimplementasikan strategi PBS, terdapat penurunan perilaku dari gejala ODD yang ditampakkan partisipan. Berdasarkan hasil wawancara evaluasi intervensi kepada ibu partisipan, diketahui bahwa partisipan sudah tidak pernah terlihat marah-marah di sekolah begitupun di lokasi kerja orang tua, partisipan tidak lagi mudah tersinggung, dan lebih terkontrol dalam berbicara.

Wali kelas partisipan menambahkan bahwa partisipan tidak pernah lagi menunjukkan perilaku negatif seperti memukul teman, berdebat dengan guru, maupun menunjukkan amarah berlebihan. Guru mata pelajaran juga tidak ada yang mengeluhkan kelakuan partisipan, teman partisipan juga merasa bahwa partisipan banyak berubah tidak seperti dulu sering membuat masalah di kelas, bahkan saat ini partisipan dekat dengan temannya yang rajin beribadah sehingga menurut guru hal tersebut cukup berpengaruh terhadap perubahan perilaku partisipan. Bila dulunya partisipan memiliki teman yang nakal, maka saat ini partisipan dekat dengan teman-temannya yang berperilaku baik.

Adapun hasil evaluasi dengan teknik observasi rating scale yang diberikan kepada guru pada tanggal 18 September 2017, dapat dilihat pada tabel 5.

Tabel 5. Hasil Observasi Perilaku Partisipan Setelah Intervensi






\section{I S K U S I}

Berdasarkan hasil asesmen, diketahui bahwa partisipan mengalami oppositional defiant disorder (ODD). Partisipan menunjukkan perilaku mudah marah, sensitif, mengucapkan kata-kata kasar, dan membantah orang dewasa. Hal tersebut dapat terlihat pada hasil observasi sebelum intervensi yang menunjukkan bahwa partisipan memiliki tingkat frekuensi yang cukup tinggi dalam melakukan agresi secara verbal dan cukup sering melakukan hal-hal yang bersifat konfrontasi kepada orang lain. Bustamante (2000) mengemukakan bahwa adanya pembiaran oleh orang tua setelah anak melakukan perilaku negatif dan orang tua/guru tidak merasa terganggu, maka anak akan belajar bahwa hal tersebut adalah sesuatu yang wajar. Kazhim (2009, dalam Anggarasari, dkk., 2014) mengemukakan bahwa dalam mengatasi emosi negatif, individu dapat memilih untuk menahan emosi, menyalurkan emosi ke hal-hal yang positif, dan dapat mengungkapkannya secara verbal. Hal tersebut terjadi pada partisipan, ia memilih untuk mengungkapkan kemarahannya secara verbal sehingga mengganggu kenyamanan lingkungan sekitarnya.

Berdasarkan hasil penegakan diagnosa dengan mengacu pada DSM V, diketahui bahwa partisipan mengalami ODD dengan level sedang. Perilaku menentang partisipan lebih sering terjadi di sekolah dan di tempat kerja ibunya. AACP (2009) mengemukakan bahwa ODD disebabkan karena kombinasi dari faktor biologis, psikologis, dan sosial. Dari faktor biologis, anak memiliki orang tua yang temperamen dan memiliki stress/depresi. Dari faktor psikologis, anak memiliki hubungan yang buruk dengan orang tua, pola asuh yang mengabaikan anak. Dari faktor sosial, anak berada dalam lingkungan yang kurang baik sehingga sangat memungkinkan anak terpapar pengaruh buruk dari lingkungan pergaulannya.

Dadds dan Fraser (2003) mengemukakan bahwa ODD ditandai dengan timbulnya penentangan dalam keluarga karena adanya masalah orang tua di rumah dan pola asuh yang salah. Masalah anak lalu menggeneralisasi ke sekolah dan situasi sosial lainnya. Perilaku partisipan yang bermasalah bermula saat partisipan berusia 2 tahun, partisipan seringkali melihat ayahnya memukul dan memarahi ibunya. Hal ini berdampak pada buruknya perilaku partisipan di sekolah dan lingkungan kerja orang tua. Alvarez dan Ollendick (2003) mengemukakan bahwa ODD dapat berkontribusi terhadap terganggunya hubungan interpersonal, sering dimulai di rumah dan kemudian mencakup ke sekolah dan setting lainnya. Penolakan teman sebaya, akan semakin membuat partisipan menunjukkan perilaku menentangnya. Perilaku partisipan yang cukup impulsif membuatnya dijauhi oleh teman-temannya.

Ketidakmampuan partisipan dalam mengelola emosi berdampak pada perilakunya yang cenderung menentang dan menantang orang lain. Oleh karena itu, partisipan membutuhkan penanganan segera untuk mencegah perilakunya meningkat ke jenjang yang lebih tinggi. Pemenuhan kebutuhan yang diperlukan dapat dipenuhi melalui program intervensi positive behavior support yang diterapkan di sekolah maupun di rumah. Intervensi diberikan untuk membantu partisipan mengurangi perilaku yang tidak diharapkan darinya dan meningkatkan perilaku yang diharapkan. Salah satu cara untuk membantu partisipan dengan permasalahan ODD yaitu dengan memberikan dukungan atas perilaku positif yang ditampakkannya dan mengajarkan keterampilan sosial. Proses intervensi positive behavior support yang diberikan kepada partisipan berlangsung sejak tanggal 27 Maret 2017 hingga 5 September 2017. Setelah mengimplementasikan strategi positive behavior support, terdapat penurunan perilaku dari gejala-gejala ODD yang ditampakkan partisipan. Perilaku yang ditampilkan partisipan sudah mengalami penurunan dan orang tua/wali kelas sudah mampu mengontrol perilaku partisipan terutama dalam aspek agresi verbal dan perilaku konfrontatif.

Hal tersebut sesuai dengan hasil penelitian sebelumnya yang dilakukan oleh Vincent dan Tobin (2011, dalam Adhyatma, 2016) bahwa penerapan positive behavior support berdampak positif terhadap perlakuan siswa-siswa sekolah dalam memperlakukan siswa dengan anak berkebutuhan khusus dan

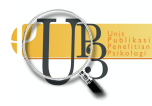


menunjukkan peningkatan keaktifan siswa dalam berbagai kegiatan pembelajaran. Hal ini menunjukkan bahwa positive behavior support membawa dampak positif terhadap perubahan perilaku siswa menjadi lebih baik.

\section{S I M P U L A N}

Berdasarkan hasil analisa secara deskriptif dapat disimpulkan bahwa metode positive behavior support dapat menurunkan gejala-gejala oppositional defiant disorder. Pada penelitian ini, setelah diberikan intervensi selama \pm 6 bulan, partisipan menunjukkan penurunan dalam melakukan agresi secara verbal dan perilaku konfrontatif.

Peneliti selanjutnya dapat mengembangkan penelitian serupa dengan menambahkan intervensi konseling keluarga bagi orang tua. Hal ini diharapkan mampu mendukung efektivitas proses intervensi positive behavior support. Selain itu, peneliti selanjutnya dapat memperbanyak sampel penelitian sehingga hasil penelitian dapat digeneralisasikan pada populasi yang lebih luas. Selain itu, kepada para ilmuwan, psikolog, dan praktisi psikologi di bidang pendidikan dan perkembangan, dapat melakukan psikoedukasi kepada masyarakat terkait penanganan emosi dan perilaku pada anak dengan oppositional defiant disorder sehingga hasil penelitian yang dilakukan dapat memberikan sumbangan secara nyata bagi permasalahan yang terjadi dalam masyarakat.

\section{UCAPA N TERIMA KAS IH}

Penulis mengucapkan terimakasih kepada partisipan penelitian, orang tua partisipan penelitian, dan wali kelas yang bersedia bekerjasama dalam melaksanakan intervensi hingga akhir. Secara khusus, penulis mengucapkan terimakasih kepada Dr. Duta Nurdibyanandaru, MS., Psikolog yang telah memberikan supervisi kepada penulis dalam melakukan asesmen dan intervensi psikologis.

\section{DEKLARAS I POTENSI TERJADINYAKONFLIK KEPENTINGAN}

Andi Ahmad Ridha tidak bekerja, menjadi konsultan, memiliki saham, atau menerima dana dari perusahaan atau organisasi mana pun yang akan mengambil untung dari naskah ini, dan telah mengungkapkan bahwa ia tidak memiliki afiliasi selain yang telah disebut di atas.

\section{PUST AKA ACUAN}

Adhyatma, M. D. R. (2016). Pengaruh penerapan positive behaviour support terhadap pengembangan budaya inklusi. INSAN Jurnal Psikologi Dan Kesehatan Mental, 1(01), 22-34.

Alvarez, H. K., \& Ollendick, T. H. (2003). Individual and psychosocial risk factors. Dalam Conduct and Oppositional Defiant Disorders (pp. 105-124). Routledge.

American Academy of Child and Adolescent Psychiatry (AACP). (2009). ODD: A Guide for Families. American Academy of Child and Adolescent Psychiatry. Diunduh dari https://www.aacap.org/App_Themes/AACAP/docs/resource_centers/odd/odd_resource_cente r_odd_guide.pdf

Anggarasari, N. H., Nashori, F., \& Kumolohadi, R. A. R. (2014). Terapi tawa untuk mengurangi emosi

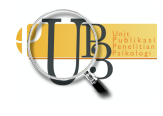


marah pada caregiver lansia. JIP (Jurnal Intervensi Psikologi), 6(1), 69-80.

Bambara, L. M., \& Kern, L. (2005). Individualized supports for students with problem behaviors: Designing positive behavior plans. Guilford Press.

Burke, J. D., Loeber, R., \& Lahey, B. B. (2003). Course and outcome. Dalam C. A. Essau (Ed.), Conduct and oppositional defiant disorders: Epidemiology, risk factors, and treatment (pp. 61-96). Routledge.

Bustamante, E. M. (2000). Treating the Disruptive Adolescent: Finding the Real Self Behind Oppositional Defiant Disorders. Jason Aronson, Incorporated.

Dadds, M. R., \& Fraser, J. A. (2003). Prevention programs. Dalam C. A. Essau (Ed.), Conduct and oppositional defiant disorders: Epidemiology, risk factors, and treatment (pp. 193-222). Routledge.

Matthys, W., \& Lochman, J. E. (2010). Oppositional defiant disorder and conduct disorder in childhood. Wiley Online Library.

Stamp, M. R. (2005). Encyclopedia of School Psychology. (S. W. Lee, Ed.). SAGE. 